\title{
Reclassification of Amycolatopsis orientalis DSM 43387 as Amycolatopsis benzoatilytica sp. nov.
}

\author{
Correspondence \\ Rup Lal \\ duzdel@vsnl.com
}

\author{
Swati Majumdar, ${ }^{1}$ S. R. Prabhagaran, ${ }^{2}$ S. Shivaji ${ }^{2}$ and Rup Lal ${ }^{1}$ \\ ${ }^{1}$ Molecular Biology Laboratory, Department of Zoology, University of Delhi, Delhi - 110007 , \\ India \\ ${ }^{2}$ Center for Cellular and Molecular Biology, Hyderabad - 500 007, India
}

\begin{abstract}
Amycolatopsis orientalis DSM 43387, a clinical isolate from submandibular mycetoma tissue, is one of three plasmid-bearing strains of the genus Amycolatopsis. It degrades aromatic compounds such as $m$-hydroxybenzoate, but does not produce any antibiotics, in contrast to Amycolatopsis orientalis NBRC $12806^{\top}$. Phylogenetic analysis based on a complete $16 \mathrm{~S}$ rRNA gene sequence placed the strain in the clade of Amycolatopsis albidoflavus IMSNU $22139^{\top}$, distant from the clade of $A$. orientalis NBRC $12806^{\top}$. The strain showed low DNA-DNA hybridization values of $24 \cdot 1$ and $45 \cdot 7 \%$ with $A$. orientalis NBRC $12806^{\top}$ and $A$. albidoflavus DSM $44639^{\top}$ ( = IMSNU $22139^{\top}$ ), respectively. It could also be readily distinguished from $A$. orientalis NBRC $12806^{\top}$ and all species with validly published names classified in the genus Amycolatopsis, by using a combination of chemical and physiological markers such as utilization of lactose, degradation of xanthine, hypoxanthine, gelatin and casein and hydrolysis of Tween 80 , indicating that it represents a novel species. Strain DSM 43387 could also be differentiated from $A$. orientalis NBRC $12806^{\top}$ and its nearest neighbour $A$. albidoflavus IMSNU $22139^{\top}$ on the basis of fatty acid and phospholipid profiles. Based on genotypic and phenotypic differences, the name Amycolatopsis benzoatilytica sp. nov. is proposed for strain DSM 43387 that was previously classified as Amycolatopsis orientalis. The type strain is AK $16 / 65^{\top}$ (=DSM $43387^{\top}=$ ATCC $55165^{\top}=$ IMRU $1389^{\top}$ ).
\end{abstract}

The genus Amycolatopsis, proposed by Lechevalier et al. (1986), comprises a large group of medically and commercially important amycolate, nocardioform actinomycetes. It belongs in the family Pseudonocardiaceae (Embley et al., 1988; Warwick et al., 1994), which is characterized by the presence of meso-diaminopimelic acid, arabinose and galactose in the wall peptidoglycan (wall chemotype IV sensu Lechevalier \& Lechevalier, 1970), $N$-acetylated muramic acid residues and fatty acids rich in iso- and anteisobranched components, but its members lack mycolic acids (Takahashi, 2001). Currently, 26 species with validly published names constitute the genus Amycolatopsis.

Most members of the genus Amycolatopsis are commercially important because of their ability to produce bioactive compounds, such as antibiotics, and to degrade a wide range of aromatic compounds. Amycolatopsis orientalis DSM 43387 does not appear to produce antibiotics. Interestingly, it

The GenBank/EMBL/DDBJ accession number for the $16 \mathrm{~S}$ rRNA gene sequence of strain DSM $43387^{\top}$ is AY957506.

Tables detailing DNA-DNA relatedness values and the differential distribution of phospholipids of Amycolatopsis benzoatilytica sp. nov. DSM $43387^{\top}$ and the type strains of $A$. orientalis and $A$. albidoflavus are available as supplementary data in IJSEM Online. metabolizes $m$-hydroxybenzoate through a central intermediate protocatechuate, unlike other species of Amycolatopsis and Streptomyces that are not able to utilize this compound as a substrate for growth (Grund et al., 1990). In addition, it also contains a $29.6 \mathrm{~kb}$ conjugative plasmid, pA387 (Lal et al., 1991), and is thus one of three plasmidbearing strains of Amycolatopsis so far reported (Dhingra et al., 2003). Strain DSM 43387 was isolated in Czechoslovakia from a patient suffering from submandibular mycetoma (Scharfen, 1971). The strain was initially identified as Nocardia brasiliensis (Scharfen, 1971) and deposited in IMRU under the accession number 1389. N. brasiliensis IMRU 1389 was reclassified as a member of Nocardia orientalis by Gordon et al. (1978), based on morphological and biochemical properties (acid production from erythritol and arabinose and decomposition of casein, hypoxanthine, tyrosine, urea, aesculin and starch) typical of N. orientalis (Mishra et al., 1980). However, the authors emphasized that the availability of more strains from different sources and a detailed study of their properties would be required to establish the status of the test strain as representing a distinct species (Gordon et al., 1978). At the time when the mycolic acid-lacking nocardioform actinomycetes were separated from the genus Nocardia, N. orientalis was renamed Amycolatopsis orientalis (Lechevalier et al., 1986). 
It therefore appears that $A$. orientalis DSM 43387 ( = IMRU 1389) has been misclassified in this species. The present investigation was designed to establish the taxonomic position of strain DSM 43387 on the basis of the 16S rRNA gene sequence, DNA-DNA hybridization, chemotaxonomy and morphological and biochemical properties. The genotypic and phenotypic data show that strain DSM 43387 should be reclassified as the type strain of a novel species of Amycolatopsis, for which the name Amycolatopsis benzoatilytica sp. nov. is proposed.

Genomic DNA was isolated from strain DSM 43387 by using the salting-out method described by Kieser et al. (2000). PCR amplification and sequencing of the 16S rRNA gene were carried out as described by Reddy et al. (2000). An almost complete $16 \mathrm{~S}$ rRNA gene sequence was determined for strain DSM 43387 (1417 nucleotides). The resultant sequence was first manually aligned with corresponding $16 \mathrm{~S}$ rRNA gene sequences of 24 species of the genus Amycolatopsis with validly published names retrieved from GenBank (http://www.ncbi.nlm.nih.gov/), using the CLUSTAL_X program (version 1.8b; Thompson et al., 1997). Phylogenetic comparison of the $16 \mathrm{~S}$ rRNA gene sequence of strain DSM 43387 with the corresponding sequences of representative members of the family Pseudonocardiaceae showed that the organism belongs to the genus Amycolatopsis. The levels of $16 \mathrm{~S}$ rRNA gene sequence similarity between strain DSM 43387 and other members of species of the genus Amycolatopsis with validly published names ranged from $91 \cdot 0$ to $95 \cdot 4 \%$. Strain DSM 43387 had a sequence similarity of $93.9 \%$ with A. orientalis NBRC $12806^{\mathrm{T}}$ and it was also revealed that its closest relative was Amycolatopsis albidoflavus IMSNU $22139^{\mathrm{T}}$, with a sequence similarity of $95 \cdot 4 \%$. These values corresponded to 63 and 83 nucleotide differences out of 1372 nucleotides positions compared. For the construction of the phylogenetic tree, the sequence alignment was optimized manually and the terminal nucleotides were removed. The tree was constructed using the neighbour-joining method (Saitou \& Nei, 1987), maximum-likelihood (Felsenstein, 1981) and parsimony analysis based on 1372 nucleotides present in all the strains, using the PHYLIP package (version 3.5c; Felsenstein, 1993). Prauserella rugosa DSM $43194^{\mathrm{T}}$ was used as an outgroup. The evolutionary distance matrix was calculated using the distance model of Jukes \& Cantor (1969). The resultant tree topologies were evaluated by bootstrap analysis based on 1000 resamplings using the programs SEQBOOT and CONSENSE. It is clear from the phylogenetic tree that strain DSM 43387 forms a monophyletic clade with A. albidoflavus IMSNU $22139^{\mathrm{T}}$ (Fig. 1). The type strain, A. orientalis NBRC $12806^{\mathrm{T}}$, forms a distinct phyletic clade distant from strain DSM 43387. Similar tree topologies were obtained using maximum-likelihood and parsimony analysis (data not shown). This clearly indicates that strain DSM 43387 forms a new centre of taxonomic variation in the genus Amycolatopsis and is quite distant from A. orientalis NBRC $12806^{\mathrm{T}}$ in the 16S rRNA gene-based phylogenetic tree. Thus phylogenetic clustering indicates that strain DSM 43387 represents a novel species of the genus Amycolatopsis.

The 16S rRNA gene does not have enough discriminatory power for use for the delineation of closely related species. Therefore the gold-standard method for species delineation to date is DNA-DNA hybridization (Wayne et al., 1987; Stackebrandt \& Goebel, 1994). To further clarify the taxonomic status of strain DSM 43387, A. orientalis NBRC $12806^{\mathrm{T}}$ and its phylogenetic neighbour A. albidoflavus DSM $44639^{\mathrm{T}}$ ( = IMSNU $22139^{\mathrm{T}}$ ) were obtained from NBRC and DSMZ, respectively, and DNA-DNA hybridization was performed using the membrane filter method (Tourova \& Antonov, 1987). First, genomic DNA was isolated from strain DSM 43387, A. orientalis NBRC $12806^{\mathrm{T}}$ and A. albidoflavus DSM $44639^{\mathrm{T}}$ by using the salting-out method described by Kieser et al. (2000). Experiments to determine DNA-DNA relatedness between the strains were performed as described by Bala et al. (2004). DNA $(10 \mu \mathrm{g})$ of each strain was transferred onto a nylon membrane (Hybond-N; Amersham) using a dot-blot apparatus (Bio-Rad). The membrane was air-dried and UV cross-linked. The DNA probe of each strain was labelled with $\left[\alpha-{ }^{32} \mathrm{P}\right]$ (BRIT) using a nick translation kit (Bangalore Genei). Hybridization was done overnight at $65^{\circ} \mathrm{C}$. After hybridization, the nylon membrane was washed twice, first with $0 \cdot 5 \times$ SSC and $0 \cdot 1 \%$ SDS for $10 \mathrm{~min}$ at room temperature and then with $0 \cdot 1 \times \mathrm{SSC}$ and $0.5 \%$ SDS for $20 \mathrm{~min}$ at $65^{\circ} \mathrm{C}$, to remove the unbound probe. The amount of bound probe DNA was estimated by using a scintillation counter (Beckman Instruments) and the hybridization values obtained were expressed as the percentage of the probe bound relative to the homologous reaction. In the experiments, DNA of each of the three strains was bound to the filters and hybridized with DNA probes prepared from each strain. The DNA-DNA hybridization data showed that strain DSM 43387 had DNA-DNA relatedness values of $24 \cdot 1$ and $45 \cdot 7 \%$, respectively, with $A$. orientalis NBRC $12806^{\mathrm{T}}$ and A. albidoflavus DSM $44639^{\mathrm{T}}$ ( = IMSNU $\left.22139^{\mathrm{T}}\right)$ at the genome level. The hybridization value of below $70 \%$, which has been suggested as the threshold value for delineating a bacterial species (Wayne et al., 1987), clearly indicated that strain DSM 43387 represents a novel species of Amycolatopsis. The percentage relatedness calculated on the basis of the data obtained (mean of four replicates) by DNA-DNA hybridization is summarized in Supplementary Table S1 in IJSEM Online.

These data support the $16 \mathrm{~S}$ rRNA gene sequence results and lead to the conclusion that strain DSM 43387 represents a novel species of Amycolatopsis.

The polar lipids of strain DSM 43387 have already been reported (Yassin et al., 1993). Analysis of the polar lipids revealed that the phospholipid pattern of strain DSM 43387 is type PII (Lechevalier et al., 1977). The polar lipid profile contained the acidic lipids diphosphatidylglycerol, phosphatidylglycerol and phosphatidylinositol, and the neutral lipids phosphatidylethanolamine and phosphatidylmethylethanolamine, as predominant phospholipids, together with 


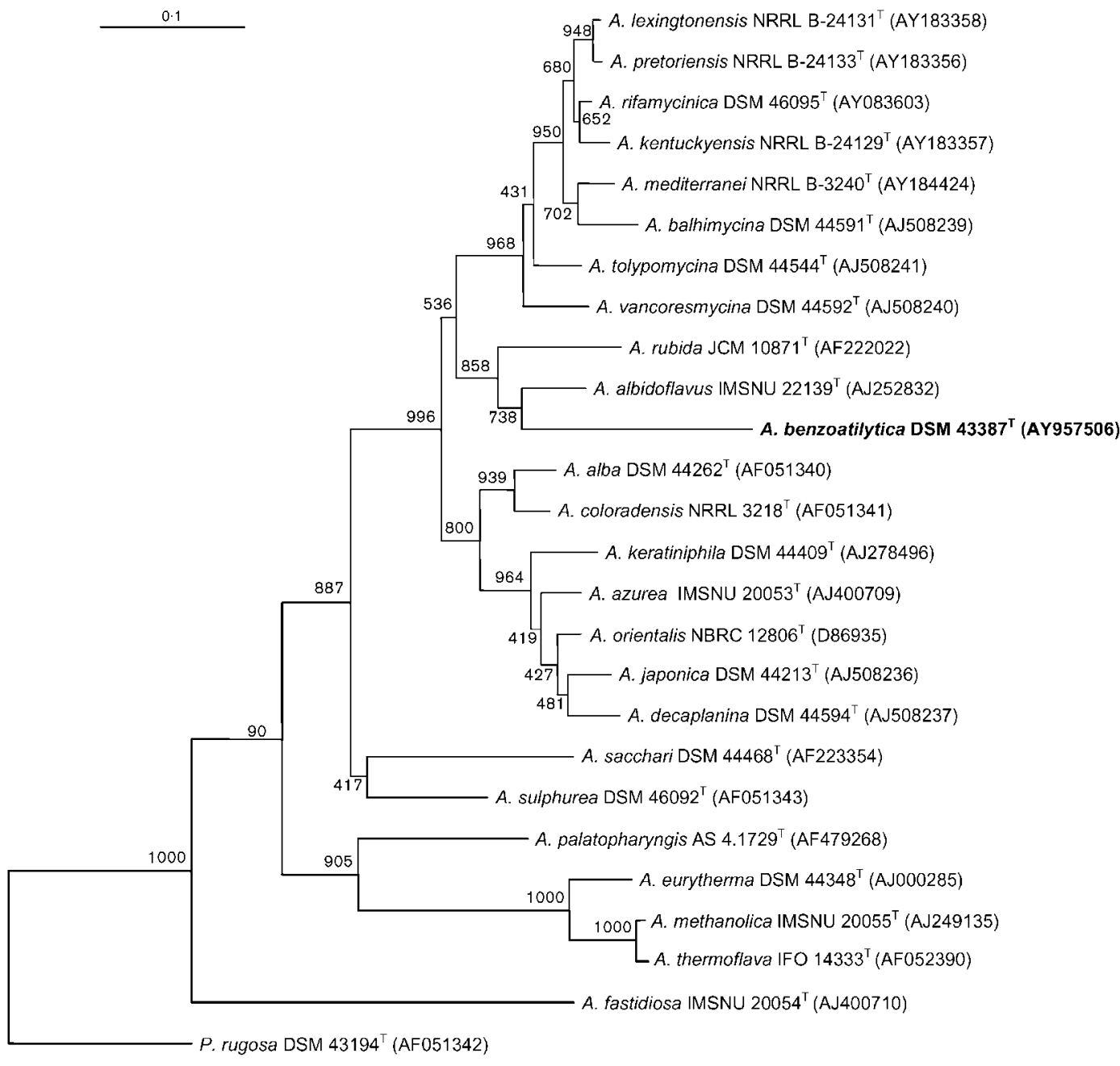

Fig. 1. Phylogenetic tree based on nearly complete $16 \mathrm{~S}$ rRNA gene sequences of species of Amycolatopsis with validly published names and Amycolatopsis benzoatilytica sp. nov. The tree was constructed by using the neighbour-joining method (Saitou \& Nei, 1987) and rooted using Prauserella rugosa DSM $43194^{\top}$ as an outgroup. Numbers at nodes are bootstrap values based on 1000 resamplings. Bar, $0 \cdot 1$ nucleotide substitution per nucleotide position.

several unidentified ninhydrin-positive phospholipids that were not present in A. orientalis NBRC $12806^{\mathrm{T}}$. In contrast, several phospholipids possessing vicinal $\mathrm{OH}$ groups (designated $\mathrm{P}-\mathrm{OH}$ ) and reacting with periodate-Schiff's reagent were present in A. orientalis NBRC $12806^{\mathrm{T}}$, in addition to the major components of the PII type phospholipid pattern, but phosphatidylinositol was absent. As shown in Supplementary Table S2 in IJSEM Online, phosphatidylglycerol, which is present as a major component in strain DSM 43387, was not present in A. albidoflavus IMSNU $22139^{\mathrm{T}}$. Whereas the polar lipid composition underlies the integrity of the genus Amycolatopsis, it clearly differentiates strain DSM 43387 from A. orientalis ATCC $19795^{\mathrm{T}}\left(=\mathrm{NBRC} 12806^{\mathrm{T}}\right)$ (Yassin et al., 1993) and A. albidoflavus IMSNU $22139^{\mathrm{T}}$ (Lee \& Hah, 2001).

Because of the uneven distribution of fatty acids among different species of actinomycetes, they are a useful criterion for the delineation of species. Cellular fatty acid analysis of strain DSM 43387, A. orientalis NBRC $12806^{\mathrm{T}}$ and A. albidoflavus DSM $44639^{\mathrm{T}}$ was carried out by Microbial ID using the following procedure. Cultures of all three strains were grown on tryptic soy agar (TSBA; Himedia Laboratories Pvt. Ltd) under similar growth conditions and fatty acid methyl esters from $40 \mathrm{mg}$ cells scraped from Petri plates were analysed by saponification, methylation and extraction, using the method of Sasser (1990). The fatty acid methyl ester mixtures were separated using the Sherlock Microbial Identification System (Microbial ID), which consisted of an Agilent model 5980 gas chromatograph fitted with a phenylmethyl silicon column $(25 \mathrm{~m} \times 0.2 \mathrm{~mm})$ and FID detector. Identification and comparison was carried out using the Aerobe (TSBA50, version 5) database of the Sherlock Microbial Identification System. The predominant fatty acids detected in the cell hydrolysate of strain DSM 43387 included 12-methyltridecanoic acid (iso- $\mathrm{C}_{14: 0}$; 
$11 \cdot 25 \%)$, pentadecanoic acid $\left(\mathrm{C}_{15: 0} ; 14 \cdot 60 \%\right)$, pentadecenoic acid $\left(\mathrm{C}_{15: 1} \omega 6 c ; 12 \cdot 81 \%\right)$, 14-methylpentadecanoic acid (iso- $\left.\mathrm{C}_{16: 0} ; 12 \cdot 80 \%\right)$, heptadecanoic acid $\left(\mathrm{C}_{17: 0}\right.$; $11 \cdot 31 \%)$ and heptadecenoic acid $\left(\mathrm{C}_{17: 1} \omega 8 c ; 11 \cdot 31 \%\right)$. The predominant fatty acids of $A$. orientalis NBRC $12806^{\mathrm{T}}$ and $A$. albidoflavus DSM $44639^{\mathrm{T}}$ were heptadecenoic acid $\left(\mathrm{C}_{17: 1} \omega 8 c ; 17 \cdot 08 \%\right)$ and 14-methylpentadecanoic acid (iso- $\mathrm{C}_{16: 0} ; 16 \cdot 74 \%$ ), respectively. A comparison of the fatty acid compositions of strain DSM 43387, A. orientalis NBRC $12806^{\mathrm{T}}$ and A. albidoflavus DSM $44639^{\mathrm{T}}$ is given in Table 1 . However, the fatty acid profiles of $A$. orientalis NBRC $12806^{\mathrm{T}}$ ( = IMSNU $20058^{\mathrm{T}}$ ) and A. albidoflavus DSM $44639^{\mathrm{T}}$ ( = IMSNU 22139 ${ }^{\mathrm{T}}$ ) determined using TSBA varied from those obtained previously for these strains on YMG broth (Lee \& Hah, 2001).

On the basis of their cellular fatty acid composition, strain DSM 43387 differed from A. orientalis NBRC $12806^{\mathrm{T}}$ and its phylogenetic neighbour A. albidoflavus DSM $44639^{\mathrm{T}}$,

Table 1. Cellular fatty acid compositions (\%) of $A$. benzoatilytica sp. nov. DSM $43387^{\top}, A$. orientalis NBRC $12806^{\top}$ and $A$. albidoflavus DSM $44639^{\top}$

Strains: 1, A. benzoatilytica DSM $43387^{\mathrm{T}} ; 2$, A. orientalis NBRC $12806^{\mathrm{T}} ; 3$, A. albidoflavus DSM $44639^{\mathrm{T}}$. All data from this study. - , Not detected.

\begin{tabular}{|c|c|c|c|}
\hline Fatty acid & 1 & 2 & 3 \\
\hline iso- $\mathrm{C}_{13: 0}$ & $0 \cdot 15$ & $0 \cdot 18$ & - \\
\hline $\mathrm{C}_{13: 0}$ & $0 \cdot 31$ & $0 \cdot 34$ & $0 \cdot 36$ \\
\hline iso- $\mathrm{C}_{14: 0}$ & $11 \cdot 25$ & $5 \cdot 97$ & $11 \cdot 02$ \\
\hline $\mathrm{C}_{14: 1} \omega 5 c$ & - & - & $0 \cdot 27$ \\
\hline $\mathrm{C}_{14: 0}$ & $0 \cdot 50$ & $0 \cdot 51$ & $1 \cdot 31$ \\
\hline iso- $\mathrm{C}_{15: 0}$ & $6 \cdot 75$ & $14 \cdot 25$ & $9 \cdot 17$ \\
\hline anteiso- $\mathrm{C}_{15: 0}$ & $3 \cdot 04$ & $1 \cdot 88$ & $2 \cdot 79$ \\
\hline $\mathrm{C}_{15: 1} \omega 6 c$ & $12 \cdot 81$ & $5 \cdot 12$ & $12 \cdot 43$ \\
\hline $\mathrm{C}_{15: 0}$ & $14 \cdot 60$ & $7 \cdot 19$ & $9 \cdot 00$ \\
\hline iso- $\mathrm{C}_{14: 0} 3-\mathrm{OH}$ & - & - & $0 \cdot 31$ \\
\hline iso- $\mathrm{C}_{16: 1} \mathrm{H}$ & $0 \cdot 21$ & $0 \cdot 27$ & - \\
\hline iso- $\mathrm{C}_{16: 0}$ & $12 \cdot 80$ & $14 \cdot 89$ & $16 \cdot 74$ \\
\hline Summed feature $3^{*}$ & $6 \cdot 79$ & $14 \cdot 25$ & $15 \cdot 31$ \\
\hline $\mathrm{C}_{16: 0}$ & $5 \cdot 15$ & $4 \cdot 68$ & $8 \cdot 95$ \\
\hline $\mathrm{C}_{15: 0} 2-\mathrm{OH}$ & $1 \cdot 01$ & $0 \cdot 79$ & $0 \cdot 75$ \\
\hline Summed feature $4^{*}$ & - & $0 \cdot 27$ & - \\
\hline anteiso- $\mathrm{C}_{17: 1} \omega 9 c$ & $0 \cdot 35$ & - & - \\
\hline iso- $\mathrm{C}_{17: 0}$ & $0 \cdot 37$ & $1 \cdot 72$ & $0 \cdot 62$ \\
\hline anteiso- $\mathrm{C}_{17: 0}$ & $0 \cdot 82$ & $1 \cdot 37$ & $1 \cdot 74$ \\
\hline $\mathrm{C}_{17: 1} \omega 8 c$ & $11 \cdot 31$ & $17 \cdot 08$ & $4 \cdot 69$ \\
\hline $\mathrm{C}_{17: 0}$ & $11 \cdot 31$ & $7 \cdot 44$ & $3 \cdot 85$ \\
\hline $\mathrm{C}_{18: 1} \omega 7 c$ & $0 \cdot 09$ & - & - \\
\hline $\mathrm{C}_{18: 1} \omega 9 c$ & - & $0 \cdot 95$ & - \\
\hline $\mathrm{C}_{18: 0}$ & $0 \cdot 37$ & $0 \cdot 84$ & $0 \cdot 70$ \\
\hline
\end{tabular}

*Summed feature $3, \mathrm{C}_{16: 1} \omega 6 c / \mathrm{C}_{16: 1} \omega 7 c$; summed feature 4,10 methyl $\mathrm{C}_{16: 0}$ /iso- $\mathrm{C}_{17: 1} \omega 9 c$. indicating that strain DSM 43387 probably represents a novel species of Amycolatopsis.

The colour, shape, size and contour of colonies of strain DSM 43387 were observed on YM medium at $28^{\circ} \mathrm{C}$ for 7 days. Cream-coloured, irregularly shaped, rough, dull and moderate-sized flat colonies with undulating margins were observed. The vegetative mycelia showed a tendency to fragment when the organism was grown in liquid culture. Similar to A. orientalis NBRC $12806^{\mathrm{T}}$, strain DSM $43387 \mathrm{did}$ not produce spores in any of the media tested. The strain was subjected to a battery of physiological tests. Growth at different temperatures and catalase tests were carried out as described by McCarthy \& Cross (1984) using YM medium. Hydrolysis of Tween 80 and the ability of the strain to grow in the presence of $\mathrm{NaCl}$ were tested as described by ArdenJones et al. (1979). Acid production from carbohydrates and degradation of xanthine and hypoxanthine were determined as described by Gordon et al. (1974). Urease activity was detected as described by Christensen (1946). Other physiological tests and methods used were as described by Collins et al. (1989). Strain DSM 43387 grew at a temperature range of $10-37^{\circ} \mathrm{C}$. The $\mathrm{pH}$ range for growth was 5-10. Similar to A. orientalis NBRC $12806^{\mathrm{T}}$ and A. albidoflavus IMSNU $22139^{\mathrm{T}}$, strain DSM 43387 utilized adonitol, $(+)$-L-arabinose, $(+)$-D-cellobiose, meso-erythritol, $(+)$ D-fructose, (+)-D-galactose, myo-inositol, (+)-D-lactose, $(+)$-D-mannose, $(+)$-D-trehalose and $(+)$-D-xylose and degraded aesculin. However, differences in results from those for A. albidoflavus IMSNU $22139^{\mathrm{T}}$ and $A$. orientalis NBRC $12806^{\mathrm{T}}$ were observed in acid production from dextrin, (+)-D-glucose, (+)-D-maltose, $(+)$-L-rhamnose and sucrose and in decomposition of casein, gelatin, xanthine and hypoxanthine and hydrolysis of Tween 80 . Differential properties of strain DSM 43387, A. orientalis NBRC $12806^{\mathrm{T}}$ and A. albidoflavus IMSNU $22139^{\mathrm{T}}$ are shown in Table 2. The differences in chemical and physiological data between strain DSM 43387 and the reference strains support the results of the $16 \mathrm{~S}$ rRNA gene analysis, DNADNA hybridization and polar lipid and fatty acid analyses.

The differences at genetic, phenotypic and chemotaxonomic levels indicate that strain DSM 43387 is different from $A$. orientalis NBRC $12806^{\mathrm{T}}$ (=IMSNU $20058^{\mathrm{T}}=$ ATCC $19795^{\mathrm{T}}$ ) and A. albidoflavus DSM $44639^{\mathrm{T}}$ ( = IMSNU $\left.22139^{\mathrm{T}}\right)$. Moreover, the tree topographies strongly suggest that strain DSM 43387 represents a novel species of Amycolatopsis. These observations clearly demonstrate that DSM 43387 should be reclassified as representing a novel species of the genus Amycolatopsis, for which the name Amycolatopsis benzoatilytica sp. nov. is proposed.

\section{Description of Amycolatopsis benzoatilytica sp. nov.}

Amycolatopsis benzoatilytica (ben.zo.a.ti.ly'ti.ca. N.L. n. benzoas -atis benzoate; Gr. adj. lutikos able to loose, able to dissolve; N.L. adj. lyticus - $a-u m$ dissolving; N.L. fem. adj. benzoatilytica benzoate-degrading). 
Table 2. Differential phenotypic characteristics of $A$ benzoatilytica sp. nov. DSM $43387^{\top}$

Strains: 1, A. benzoatilytica DSM $43387^{\mathrm{T}} ; 2$, A. orientalis NBRC $12806^{\mathrm{T}}$; 3, A. albidoflavus IMSNU $22139^{\mathrm{T}}$ (data from Lee \& Hah, 2001). +, Positive reaction; -, negative reaction; ND, not determined. All strains are negative for production of soluble pigment. All strains produce acid from adonitol, (+)-D-arabinose, (+)-Dcellobiose, meso-erythritol, (+)-D-fructose, $(+)$-D-galactose, $(+)$ D-lactose, (+)-D-mannose, myo-inositol, (+)-D-trehalose and $(+)$-D-xylose, but do not assimilate $(+)$-D-raffinose or (-)-Dsorbitol. All strains decompose aesculin and are catalase-positive.

\begin{tabular}{|lccc|}
\hline Characteristic & $\mathbf{1}$ & $\mathbf{2}$ & $\mathbf{3}$ \\
\hline Acid production from: & & & \\
$\quad$ Dextrin & + & + & - \\
$\quad(+)$-D-Glucose & + & + & - \\
$\quad(+)$-D-Maltose & - & + & - \\
$\quad(+)$-L-Rhamnose & + & + & - \\
Sucrose & - & + & + \\
Decomposition of: & & & \\
Allantoin & + & + & ND \\
Gelatin & - & + & + \\
Xanthine & - & + & + \\
Hypoxanthine & - & + & + \\
Casein & - & + & + \\
Hydrolysis of: & & & \\
Tween 80 & - & + & ND \\
Starch & - & - & + \\
& & & \\
\end{tabular}

Cells are aerobic, non-motile, non acid-fast, Gram-positive, filamentous and differentiated into substrate and aerial mycelia. Vegetative mycelia have the tendency to fragment when the organism is grown in liquid culture. Creamcoloured aerial mycelium is produced on YM, nutrient agar, TSBA and Bennett's agar. Catalase- and urease-positive but amylase-negative. Soluble pigment is not produced. Acid is produced from adonitol, $(+)$-L-arabinose, $(+)$-D-cellobiose, dextrin, meso-erythritol, $(+)$-D-fructose, $(+)$-D-glucose, $(+)$ D-galactose, myo-inositol, $(+)$-D-lactose, $(-)$-D-mannitol, $(+)$-D-mannose, $(+)$-L-rhamnose, $(-)$-D-ribose, $(+)$-Dtrehalose and $(+)$-D-xylose. Utilizes $(+)$-D-raffinose but not $(-)$-D-sorbitol or sucrose. Hydrolyses aesculin and decomposes allantoin. Tween 80 , starch, casein, gelatin, xanthine and hypoxanthine are not hydrolysed or decomposed. Saturated, unsaturated and branched fatty acids are present. The predominant fatty acids are 12-methyltridecanoic acid (iso- $\left.\mathrm{C}_{14: 0}\right)$, pentadecanoic acid $\left(\mathrm{C}_{15: 0}\right)$, pentadecenoic acid $\left(\mathrm{C}_{15: 1} \omega 6 c\right), 14$-methylpentadecanoic acid (iso- $\left.\mathrm{C}_{16: 0}\right)$, heptadecanoic acid $\left(\mathrm{C}_{17: 0}\right)$ and heptadecenoic acid $\left(\mathrm{C}_{17: 1} \omega 8 c\right)$. The phospholipid profile is type PII and contains diphosphatidylglycerol, phosphatidylglycerol, phosphatidylinositol, phosphatidylethanolamine and phosphatidylmethylethanolamine. Growth occurs at $\mathrm{pH} 5 \cdot 0-10 \cdot 0$. Grows in the presence of $5 \% \mathrm{NaCl}$. The temperature range for growth is $10-37^{\circ} \mathrm{C}$. Degrades $m$-hydroxybenzoate. Contains the $29 \cdot 6 \mathrm{~kb}$ conjugative plasmid pA387.
The type strain, AK $16 / 65^{\mathrm{T}}\left(=\mathrm{DSM} \quad 43387^{\mathrm{T}}=\mathrm{ATCC}\right.$ $55165^{\mathrm{T}}=$ IMRU $1389^{\mathrm{T}}$ ), was isolated in Czechoslovakia from a patient with submandibular mycetoma by Scharfen (1971) (Institute of Epidemiology and Microbiology, Prague).

\section{Acknowledgements}

This work was supported by grants from the Department of Science and Technology (DST), Government of India. S. M. gratefully acknowledges UGC (Government of India) for providing the research fellowship. We would like to thank J. P. Euzéby for etymological advice.

\section{References}

Arden-Jones, M. P., McCarthy, A. J. \& Cross, T. (1979). Taxonomic and serologic studies on Micropolyspora faeni and Micropolyspora strains from soil bearing the specific epithet rectivirgula. J Gen Microbiol 115, 343-354.

Bala, S., Khanna, R., Dadhwal, M., Prabagaran, S. R., Shivaji, S., Cullum, J. \& Lal, R. (2004). Reclassification of Amycolatopsis mediterranei DSM 46095 as Amycolatopsis rifamycinica sp. nov. Int J Syst Evol Microbiol 54, 1145-1149.

Christensen, W. B. (1946). Urea decomposition as a means of differentiating Proteus and para-colon cultures from each other and from Salmonella and Shigella types. J Bacteriol 52, 461-466.

Collins, C. H., Lyne, P. M. \& Grange, J. M. (1989). Microbiological Methods, 6th edn. London: Butterworth.

Dhingra, G., Kumari, R., Bala, S., Majumdar, S., Malhotra, S., Sharma, P., Lal, S., Cullum, J. \& Lal, R. (2003). Development of cloning vectors and transformation methods for Amycolatopsis. J Ind Microbiol Biotechnol 30, 195-204.

Embley, T. M., Smida, J. \& Stackebrandt, E. (1988). The phylogeny of mycolate-less wall chemotype IV actinomycetes and the description of Pseudonocardiaceae fam. nov. Syst Appl Microbiol 11, 44-52.

Felsenstein, J. (1981). Evolutionary trees from DNA sequences: a maximum likelihood approach. J Mol Evol 17, 368-376.

Felsenstein, J. (1993). PHYLIP (phylogeny inference package), version 3.5c. Distributed by the author. Department of Genome Sciences, University of Washington, Seattle. USA.

Gordon, R. E., Barnett, D. A., Handerhan, J. E. \& Pang, C. H.-N. (1974). Nocardia coeliaca, Nocardia autotrophica, and the nocardin strain. Int J Syst Bacteriol 24, 54-63.

Gordon, R. E., Mishra, S. K. \& Barnett, D. A. (1978). Some bits and pieces of the genus Nocardia: N. carnea, N. vaccinii, N. transvalensis, N. orientalis and N. aerocolonigenes. J Gen Microbiol 109, 69-78.

Grund, E., Knorr, C. \& Eichenlaub, R. (1990). Catabolism of benzoate and monohydroxylated benzoates by Amycolatopsis and Streptomyces spp. Appl Environ Microbiol 56, 1459-1464.

Jukes, T. H. \& Cantor, C. R. (1969). Evolution of protein molecules. In Mammalian Protein Metabolism, pp. 21-132. Edited by H. N. Munro. New York: Academic Press.

Kieser, T., Bibb, M. J., Buttner, M. J., Chater, K. F. \& Hopwood, D. A. (2000). Practical Streptomyces Genetics. Norwich: John Innes Foundation.

Lal, R., Lal, S., Grund, E. \& Eichenlaub, R. (1991). Construction of a hybrid plasmid capable of replication in Amycolatopsis mediterranei. Appl Environ Microbiol 57, 665-671. 
Lechevalier, M. P. \& Lechevalier, H. (1970). Chemical composition as a criterion in the classification of aerobic actinomycetes. Int J Syst Bacteriol 20, 435-443.

Lechevalier, M. P., De Bièvre, C. \& Lechevalier, H. A. (1977). Chemotaxonomy of aerobic actinomycetes: phospholipid composition. Biochem Syst Ecol 5, 249-260.

Lechevalier, M. P., Prauser, H., Labeda, D. P. \& Ruan, J.-S. (1986). Two new genera of nocardioform actinomycetes: Amycolata gen. nov. and Amycolatopsis gen. nov. Int J Syst Bacteriol 36, 29-37.

Lee, S. D. \& Hah, Y. C. (2001). Amycolatopsis albidoflavus sp. nov. Int J Syst Evol Microbiol 51, 645-650.

McCarthy, A. J. \& Cross, T. (1984). A taxonomic study of Thermomonospora and other monosporic actinomycetes. J Gen Microbiol 130, 5-25.

Mishra, S. K., Gordon, R. E. \& Barnett, D. A. (1980). Identification of nocardiae and streptomycetes of medical importance. J Clin Microbiol 11, 728-736.

Reddy, G. S. N., Aggarwal, R. K., Matsumoto, G. I. \& Shivaji, S. (2000). Arthrobacter flavus sp. nov., a psychrophilic bacterium isolated from a pond in McMurdo Dry Valley, Antarctica. Int J Syst Evol Microbiol 50, 1553-1561.

Saitou, N. \& Nei, M. (1987). The neighbor-joining method: a new method for reconstructing phylogenetic trees. Mol Biol Evol 4, 406-425.

Sasser, M. (1990). Identification of bacteria by gas chromatography of cellular fatty acids, MIDI Technical Note 101. Newark, DE: MIDI Inc.

Scharfen, J. (1971). Trutonov 139-66. An unusual actinomycetes combining the contradictory properties of the genera Nocardia and Actinomyces - the causative agent of submandibular mycetoma. I. Introduction. J Hyg Epidemiol Microbiol Immunol 15, 43-51.
Stackebrandt, E. \& Goebel, B. M. (1994). Taxonomic note: a place for DNA-DNA reassociation and 16S rRNA sequence analysis in the present species definition in bacteriology. Int J Syst Bacteriol 44, 846-849.

Takahashi, Y. (2001). Family Pseudonocardiaceae. In Identification Manual of Actinomycetes, pp. 227-239. Edited by The Society for Actinomycetes, Japan. Tokyo: The Business Center for Academic Societies.

Thompson, J. D., Gibson, T. J., Plewniak, F., Jeanmougin, F. \& Higgins, D. G. (1997). The CLUSTAL_X windows interface: flexible strategies for multiple sequence alignment aided by quality analysis tools. Nucleic Acids Res 25, 4876-4882.

Tourova, T. P. \& Antonov, A. S. (1987). Identification of microorganisms by rapid DNA-DNA hybridization. Methods Microbiol 19, 333-355.

Warwick, S., Bowen, T., McVeigh, H. \& Embley, T. M. (1994). A phylogenetic analysis of the family Pseudonocardiaceae and the genera Actinokineospora and Saccharothrix with 16S rRNA sequences and a proposal to combine the genera Amycolata and Pseudonocardia in an emended genus Pseudonocardia. Int $J$ Syst Bacteriol 44, 293-299.

Wayne, L. G., Brenner, D. J., Colwell, R. R. \& 9 other authors (1987). International Committee on Systematic Bacteriology. Report of the ad hoc committee on reconciliation of approaches to bacterial systematics. Int J Syst Bacteriol 37, 463-464.

Yassin, A. F., Haggenei, B., Budzikiewicz, H. \& Schaal, K. P. (1993). Fatty acid and polar lipid composition of the genus Amycolatopsis: application of fast atom bombardment-mass spectrometry to structure analysis of underivatized phospholipids. Int J Syst Bacteriol 43, $414-420$. 